\title{
AirAsia In The Malaysian Domestic Airline Market: Empirical Analysis Of Strategy
}

Mok Kim Man, (Email: mkimman@ums.edu.my),Universiti Malaysia - Sabah, Malaysia

Jainurin Bin Justine, (Email: Jainurin@ums.edu.my), Universiti Malaysia - Sabah, Malaysia

\begin{abstract}
This paper will examine the results of the strategic actions of AirAsia in the Malaysian domestic airline market. Firstly, the paper will provide a general background of the airline industry, in particular the Malaysian domestic airline market and a summary of an analysis of the industry using Michael Porter's Five Forces Analysis. Secondly, the paper will provide a brief background of AirAsia and Malaysia Airlines. Thirdly, the paper will analyse the results of AirAsia's strategy vis-àvis operating and financial performance. Finally, the paper will conclude a summary of AirAsia's achievement of the past and present and prospect for the future.
\end{abstract}

\section{INDUSTRY BACKGROUND}

\section{Airline Industry}

The airline industry is very competitive with existing airlines having to compete with each other as well as with new entrants from time to time. For every success such as Singapore Airlines and Southwest Airlines, there are plenty of failures such as Pan Am, TWA, Swissair, Sabena, Ansett, People Express, Go, Buzz and so on.

\section{Major Characteristics}

There are three major characteristics of the airline industry namely its product nature, its expenditure structure and its market entry conditions. Airlines' product is homogeneous or undifferentiated, causing significant competition in markets, which are free from regulations and economic barriers. High capital and operating expenditure is another important characteristic of the airline industry. Aircrafts, airlines' major capital expenditure, are very costly to acquire. For operating expenditures, aviation fuel and labour make up the two major costs in the industry.

Another important characteristic of the industry is the conditions for market entry, which differs between international and domestic markets. In the international market, entry is very difficult as international flights and routes are the results of bilateral negotiations between governments. On the other hand, in the domestic and regional markets, entry depends on the level of deregulation or liberalisation. More and more countries, however, are opening up their domestic markets for more competition. In addition, government plays an important role to regulate the markets and existing players may have significant influence over new entrants.

\section{Forces Driving the Industry}

The major factors driving the industry are the global economy and safety issues. When the world or any region of it is in an economic downturn, the demand for airline services will fall. The late 1990's Asian Financial Crisis, for example, resulted in minimal increase in the number of worldwide airline passengers increased only minimally from 1997 to 1998 . Safety issues are also an important driver of the industry, which is subject to very stringent safety standards. In addition, there are also unexpected safety related events such as the 11 September 2001 tragedy in the US and the recent Severe Acute Respiratory Syndrome outbreak in East Asia, which caused reduction in passengers. 


\section{New Trend in the Industry}

The increasing popularity of low cost airlines is the newest trend in the airline industry. In the past few years, we have seen the rise of low cost airlines such as AmericaWest, JetBlue and AirTran in the US, Ryanair and easyJet in Europe and Virgin Blue in Australia. The new trend is an old concept pioneered by the US-based Southwest Airlines in the early 1970's. From then onwards, the concept caught on with many airlines adopting it. The share of low cost airlines in the US and European markets is steadily increasing.

Table 1 in the Appendix outlines, the "Southwest Strategy", the basis of most low cost airlines operations. The key of the strategy is to reduce costs while at the same time offering low prices to passengers. History showed that the strategy is easy to replicate but difficult to implement successfully.

\section{Malaysian Domestic Airline Market}

Before we delve further into the case study, it is important to have a background of the Malaysian domestic airline market by understanding the importance of its role in the country and having a concise history of the industry.

\section{Role of Airline Travel}

Airline travel within Malaysia is a critical means of transportation between the two distinct parts of the country, East Malaysia on the island of Borneo and West Malaysia on the Malay Peninsular. Due to geography, the options available to for travel across the South China Sea are airplanes and ships.

Another critical function of the airline travel is to connect the major towns and the remote interior areas within East Malaysia, which has poor road systems and limited availability of other significant means of transportation. In contrast, West Malaysia has more developed and extensive road and railway systems. Therefore, airline travel is not the main mode of long distance transportation in this part of Malaysia.

In addition, it is often mentioned that airline travel plays an important role in nation building as it facilitates in uniting and integrating the citizens on both sides of the South China Sea. Airline travel also plays a crucial role in supporting economic activities such as tourism.

\section{History of Airline Travel}

The history of domestic airline travel started in 1947 with the first passenger service from Singapore to Kuala Lumpur. From the 1970's, the domestic airline industry has always been dominated by the national career, Malaysia Airlines, which flies to between East and West Malaysia as well as within East and West Malaysia. In early 1990's, the domestic market was opened to more competition, with a number of new airlines starting services within the country (Sakran, 2002). The majority of the new entrants, however, served a very limited number of destinations and therefore, were never a threat to Malaysia Airlines' dominance.

\section{Industry Analysis of the Malaysian Domestic Airline Market}

Using Porter's five-force framework to understand the competitive structure of industries, we can conclude that the industry has a high entry barriers, it is moderately competitive and has minimal threat from substitute products, suppliers and buyers. While these factors make market an attractive to enter, high entry barriers await any potential new entrants.

\section{Rivalry Among Existing Competitors}

The industry is moderately competitive despite having only two major airlines. However, AirAsia is steadily being threatening the dominance of Malaysia Airlines. 


\section{The Threat of Entry}

The industry has a moderate to high barriers of entry. A new small airline serving one or two routes may enter easily. However, given past experiences, a larger airline serving multiple routes may be harder. The transformation of present small airlines into a larger airline is probably more likely to be successful as in AirAsia's case. Access to capital and labour are the major obstacles for new entrants.

Pressure from Substitute Products and Support from Complements

The industry is characterised by very low or minimal pressure from substitute products. The role of complements has yet to be tapped fully.

Power of Input Suppliers

The industry is characterised by low to medium power of input suppliers. It is highly unlikely that any one group of supplier to have major control over industry constituents.

Power of Buyers

The industry is characterised by low power of buyers. Like input suppliers, it is highly unlikely that any one group of buyers to have major control over industry constituents.

The "Sixth" Force

In the case of the Malaysian domestic airline market, the Government plays a key role as the regulator of the industry through the Ministry of Transportation and Department of Civil Aviation. At the same time, the Government also hold a majority a shareholding in Malaysia Airlines.

\section{COMPANY BACKGROUND}

\section{AirAsia}

AirAsia was incorporated in 1993 by the Malaysian industrial conglomerate, DRB-Hicom and a local aviation company, Mofaz Air. AirAsia was designated to operate both domestically and internationally, started services in 1996, two years. In September 2001, DRB-Hicom sold its' 99.75\% share in AirAsia to Tune Air for 1 Malaysian Ringgit (MYR) and assumption of 50 percent of AirAsia's net liability, while Mofaz Air retained the remaining $0.25 \%$ (Jaafar, 2001). In December 2001, the sale of AirAsia was finalised and it was announced that the airline was going to operate on a "no frills, less expensive domestic fares" concept. (Utusan Malaysia, 2001).

\section{Malaysia Airlines}

When the separation of the Malaysian Singapore Airlines (MSA) occurred in 1971, two new airlines were formed, Singapore Airlines and Malaysia Airlines. Singapore Airlines took the international routes and assets of the MSA, while the domestic Malaysian routes and assets were left to Malaysia Airlines. From these limited routes and assets, Malaysia Airlines grew to become what is today, a full fledge full service career. In the mid 1980's, it became the first state owned enterprise to be privatised when it was listed on the Kuala Lumpur Stock Exchange. Except for the period from the mid 1990 to early 2001, the airline was owned primarily by the government. 


\section{EMPIRICAL ANALYSIS OF AIRASIA'S STRATEGIC AND ACTIONS}

\section{Review of AirAsia's Implementation Strategic Actions}

Upon takeover by new owners, AirAsia adapted a new operating model following those used by other low cost airlines such as Southwest Airlines in the US and Ryanair and Easyjet in Europe. AirAsia offered lower fares to all the destinations it served compared to Malaysia Airlines. AirAsia's fares are based on when the tickets are purchased. No frills services on AirAsia flights meant no complementary meals or drinks and no in-flight entertainment.

The following reviews in detail the execution by AirAsia of the "Southwest Strategy" (Bonne, 2002). The details of the strategy are shown in Table 1 in the Appendix. Such a review is necessary to determine whether the strategy AirAsia chose was implemented properly as the operating and financial results are meaningless without the proper implementation of the underlying strategy behind them.

No of Passengers carried

The total of number of passengers carried by both AirAsia and Malaysia Airlines have gone in opposite directions. In AirAsia's case, the number of passengers increased from 271,000 for the period from April 2000 to March 2001 to 359,000 for the period from April 2001 to March 2002. For the period from April 2002 to March 2003, the number of passengers was $1,329,000$. The increase resulted from the increase in the number of destinations served and the number of aircrafts used by the airline.

Fleet

AirAsia utilises only Boeing 737-300 aircrafts in its fleet. The airline had previously considered using Airbus aircrafts but decided against it. Boeing 737's are the aircraft of choice for most major low cost airlines around the world.

\section{Service is limited on flights}

AirAsia provides very limited "free" services on its flights. Food and drinks can be bought on-board at affordable prices to passengers. In addition, airline souvenirs such as T-shirts, caps and pens are also sold on the flights. In financial year 2002, AirAsia recorded ancillary income amounting to 7.7 million MYR or about $4 \%$ of total revenue. In the previous financial year, ancillary income was 0.1 million MYR or less than $1 \%$ of total revenue. A major source of ancillary income is aircraft advertising, whereby, AirAsia aircrafts becomes a flying billboard. A deal done with a local telecommunication company is estimated to worth 1.8 million MYR (Prystay, 2002).

\section{Service is based one single class}

There is only one class on the airline's flights - the AirAsia class, as the airline puts it. Free seating is used in the class to ensure that passengers board the aircrafts more timely. The airline's major customers, Malaysians are known to operate to "Mexican" time.

\section{Routes are point to point}

AirAsia flights are all point to point. AirAsia also introduced new routes pairing the national capital, Kuala Lumpur with a number of destinations in East Malaysia, which were previously served (and still are) by Malaysia Airlines through the major airports at the two East Malaysian state capitals. These direct flights save the time, and of course, the money of passengers. 


\section{Turnaround time in airports is short}

AirAsia targets for a 25 minutes turnaround time, the time similar to many other low cost airlines. Its performance against the target has been good as shown by the statistics reported on its website. However, one major problem for an airline with a limited number of aircrafts is that a delay for one flight may cause delays to the other flights utilising the same aircraft. Such a domino effect on the flights can have serious repercussions to passengers' view of AirAsia's services and not to mention, its turnaround target.

\section{Use of secondary airports}

AirAsia is unable to apply this strategy in Malaysia as there are no secondary airports in all the destinations it serves, with the single exception of the national capital. The airline had previously operated at the secondary airport until July 2002. However, in line with the government's ambitions to make the major airport, the Kuala Lumpur International Airport as a major hub in the region, all airlines operating jet aircrafts to operate out of KLIA instead of the secondary airports. If AirAsia operates out of the secondary airport, the airline may lose access to the international passengers, all of who arrive in KLIA.

\section{Bookings made directly to airline}

AirAsia has moved away from the major traditional distribution channel of airlines, namely travel agents. Under previous ownership, travel agents accounted for about $70 \%$ of revenue. Under current owners, only $2 \%$ of revenue is from the agents. Bookings and payments are primarily made through AirAsia's own reservations and sales offices, nationwide call centre and Internet website. Internet bookings currently make up $60 \%$ of all bookings. In August 2003, AirAsia went a step further by introducing reservations and payment via Short Messaging System (SMS) through mobile phone services. The airline claimed that the initiative was the first of its kind in the world.

In addition to the implementation of the above strategy, AirAsia has also instituted several cost savings initiatives such as the following related to Khanna (2002):

- $\quad$ Staff members are multi-task: attendants announce flight departures, pilots help to clean the plane and management helps to check in passengers.

- $\quad$ Improved landings going from 80 landings per set of tyres to 180.

- Improved on runway braking methods, usage of the reverse thruster and aircraft descent methods. As a result, AirAsia now burns 770 US gallons per hour of fuel, compared to Malaysia Airlines, using a similar plane, burns 1,100 US gallons.

- $\quad$ Ground handling is done in-house: the Chief Executive Officer sometimes helps out in this.

It is clear that AirAsia has achieved what it set out to do when it change from a full service carrier to a low cost airline. Without successful implementation of the strategy, it might have not succeeded in improving its operating and financial performance as will be shown in the following few sub-sections.

\section{Comparison of Performance with Malaysia Airlines}

The following section will compare the performance of AirAsia with that of Malaysia Airlines, with respect to operating and financial results over the period of 2001 to 2003.

\section{Comparison of Operating Results}

The key data or ratios that are normally used to compare the operating performance of passenger service airlines are as follows:

- $\quad$ No of Passengers carried

- $\quad$ Available seat-km (SKM) - Number of available seats multiplied by distance flown (in $\mathrm{km}$ ) 
- $\quad$ Revenue passenger-km (PKM) - Number of passenger carried multiplied by distance flown (in km)

- $\quad$ Passenger load factor - Revenue passenger-km expressed as a percentage of available seat-km

\section{No of Passengers carried}

The total of number of passengers carried by both AirAsia and Malaysia Airlines have gone in opposite directions. In AirAsia's case, the number of passengers increased from 271,000 for the period from April 2000 to March 2001 to 359,000 for the period from April 2001 to March 2002. For the period from April 2002 to March 2003, the number of passengers was $1,329,000$. The increase resulted from the increase in the number of destinations served and the number of aircrafts used by the airline.

For Malaysia Airlines, the number of domestic passengers decreased from 8,854,000 for the period from April 2000 to March 2001 to 8,645,000 in the period of April 2001 to March 2002. However, for the period from April 2000 to March 2001, the number of passengers has risen to 8,677,000, although, still below the figure for the same period two years before. According to the airline, the major reason for the decline was the effects from the September 11 tragedy. Malaysia Airlines maintained that the increased competition from AirAsia did not have any effect on the airline's operations. On further analysis, this claim is correct. When AirAsia started its service as a low cost airline in January 2002, Malaysia Airlines total passengers of 2,045,000 for the period from October to December 2001 fell by about $1 \%$ to 2,021,000 for the period from January to March 2002.

In terms of market share, AirAsia's has increased from 3\% in the period from April 2000 to March 2001 to 13\% in the period from April 2002 to March 2003. However, in terms of absolute numbers, Malaysia Airlines have maintained almost the same total number of passengers for the past three years being compared. The comparison of number of passengers is shown in Figure 1 in the Appendix.

In terms of the growth in number of passengers, obviously, AirAsia has grown tremendously. For example, when comparing the first half year of calendar year 2002 against first half year of calendar year 2003, the figures show that the number of passengers for AirAsia has increased by 54\% from 454,560 to 700,000, while for Malaysia Airlines, the number decreased by $6 \%$ from $4,142,000$ to 3,900,000. Malaysia Airlines blamed the SARS virus for the drop. On the other hand, AirAsia added an aircraft and three destinations during the quarter.

Based on the above information, we can expect that for the short term, AirAsia will continue to carry more passengers as it increases the number of destinations within the country, with minimal impact to Malaysia Airlines. Long-term effect on Malaysia Airlines will only be possible to measure once AirAsia's expansion in the domestic is over.

In addition, the above ratios are also reported against the number of staff that the airline employs and the number of aircrafts in the fleet to measure the efficiency of the airline. The resultant efficiency ratios are as follows:

Available seat-km (SKM), Revenue passenger-km (PKM) and Load Factor

These three ratios are interrelated. As no detail data are available for AirAsia in terms of Available seat-km (SKM) and Revenue passenger-km (PKM), no comparison can be made for these ratios. However, based on Load Factors, which is a function of both SKM and PKM, both Malaysia Airlines and AirAsia are showing similar results.

In AirAsia's case, the load factor increased from 67\% in the period of April 2001 to June 2002 to $70 \%$ in the period from July 2002 to June 2003. For Malaysia Airlines the load factor for domestic flights for periods from April 2001 to March 2002 and from April 2002 to March 2003 were 69.3\% and 74\% respectively. Malaysia Airlines has improved its load factor although nowhere near the load factor of $79.2 \%$ achieved in the period from April 2000 to March 2001. It should be noted that as low cost airlines have lower cost base, an airline like AirAsia requires lower load factors to breakeven compared to full cost airlines like Malaysia Airlines. 


\section{Financial Comparison}

For financial performance comparison, we will review revenue and profits attained by both airlines. As AirAsia is a privately held company, detailed information is not readily available. However, these two data will be able to give an insight on the growth and profitability of the two airlines.

Revenue

AirAsia has shown improvement in the revenue since takeover by its new owners and implementation of low cost airline model. In the period from April 2000 to March 2001, revenue was 167.8 million MYR. In the period from April 2001 to June 2002 (AirAsia changed financial year-end from March to June, revenue grew to 222.3 million MYR. This is an absolute growth of 32 per cent, although on annualised basis for the same 15 -month period (177.8 million MYR for 12 months), revenue grew by 6 per cent only. However, in the period from July 2002 to June 2003, AirAsia chalked up a total revenue of 330 million MYR, an increase of 86 percent (absolute) or 48 per cent (over annualised April 2001 to June 2002 period). As pointed out earlier, increase in flights contributed to the increase in revenue.

Malaysia Airlines also showed improvements on its domestic revenue. Revenue grew by 10 per cent from 1,144.2 million MYR for the period from April 2000 to March 2001 to 1,263.0 million MYR for the period from April 2001 to March 2002. In the subsequent period of from April 2002 to March 2003, revenue grew by a modest 4 per cent to 1,312.0 million MYR. As between 1998 and 2002, the airline has achieved between 10-14 per cent increase in revenue annually, the single digit increase does not bode well for the airline.

The comparison between AirAsia and Malaysia Airlines revenue is shown in Figure 2 in the Appendix. While Malaysia Airlines has contended that AirAsia operations does not have any impact on its operations, we can deduce from the differences in the growth rates that AirAsia has some impact on Malaysia Airlines domestic operations.

Profits

AirAsia has improved tremendously from the days it was under the previous owners. It was reported to have accumulated more than 145 million MYR of losses prior to the take over (Travel Trade Report, 2003). In the period from April 2001 to June 2002, the airline netted a net income of 0.232 million MYR, out of 19.1 million MYR net loss for the first seven months under the old owners and 19.4 million MYR net income for the second eight months under the new owners and new operating concept. For the period from July 2002 to June 2003, the airline recorded a net income of 20 million MYR.

Malaysia Airlines does not keep separate profit figures for its international and domestic operations. Therefore, it is improbable to compare the profitability of Malaysia Airlines against AirAsia. However, it should be noted that from 1997 to 2002, Malaysia Airlines has raked up net losses totalling to 2,471.5 million MYR or about 494.3 million MYR a year, with the highest net loss of 835.6 million MYR being for the period from April 2001 to March 2002. In the period from April 2001 to March 2002, the airline made a profit of 339.1 million MYR, primarily due to exceptional items (profit made on sale of aircraft leased back) and sale of aircrafts and spare engines. For the period from April to June 2003, Malaysia Airlines recorded a net loss of 165.5 million MYR. The outlook for the rest of the year does not look very well.

\section{Return on Revenue}

Although it is improbable to compare absolute profit figures, we can compare the returns on revenue for both AirAsia and Malaysia as measures of profitability. For the period from April 2001 to June 2002, AirAsia return on revenue is less than 1 per cent, while for Malaysia Airlines for the period from April 2001 to March 2002, return on revenue is negative 10 per cent. For the period from July 2002 to June 2003, AirAsia return on revenue is 6 per cent, 
while for Malaysia Airlines for the period from April 2001 to March 2002, return on revenue is 4 per cent. Return on revenue for the period from April to June 2002 is negative 10 per cent.

In summary, we can conclude that based on the results of operating and financial performance, AirAsia has performed much better than Malaysia Airlines. However, the long-term impact of AirAsia strategy on Malaysia Airlines will only be clear in the years to come. AirAsia strategy has been in place less than two years. As the Chief Executive Officer of AirAsia puts aptly it, "Talk to me in 10 years and I will tell you if we have been a success." (Thomas, 2003).

\section{Impact on Malaysia Airlines' Share Prices}

Since AirAsia is not a publicly traded company, there are no shares to be tracked. However, Malaysia Airlines is a publicly traded company and therefore, its shares can be tracked and analysed, which will be done in the following.

\section{Share Price Movement}

Figure 3 in the Appendix shows the movement of Malaysia Airlines shares against the Kuala Lumpur Stock Exchange (KLSE) Index (Yahoo.com, 2003). The period covered is from November 2001 to October 2003, during which AirAsia started operating as a low cost airline. As Malaysia Airlines is a constituent of the KLSE Index, we see that the prices of the airline's shares follow the movement of the KLSE Index.

\section{Analysis of Share Prices}

Two key events in AirAsia's operations for the past two years are the announcement that the airline will become a low cost airline on 15 January 2001 and the announcement of operating results of the first year of operations on 15 January 2003. In early July 2003, AirAsia also announced its results for the second year of operations. Based on the share price movement for Malaysia Airlines during these three periods, it is found that only during the first announcement in January 2002 was the share price affected somewhat adversely, i.e. going down after the announcement. In the other announcements in January 2003 and July 2003, the share prices went up. Table 2 in the Appendix shows Malaysia Airlines share prices for the two weeks within the three announcements.

We can presume that AirAsia did not have much effect on Malaysia Airlines share prices. One possible reason is the scope and size of Malaysia Airlines. Both airlines are of different sizes. Malaysia Airlines operates domestic and international flights with the bulk of revenues from the international services. For example, for the period from April 2002 to March 2003, international flights accounted for about 81.5\% of the airline's revenue from passenger operations.

\section{Valuation Of AirAsia}

The final part of this section will examine the estimated values of AirAsia.

\section{Valuation Basis}

According to Fleming $(2003,130-133)$, there are various methods to evaluate privately held companies, with the "recent" transaction and price/earning $(\mathrm{P} / \mathrm{E})$ multiple methods being the main ones.

\section{"Recent" transaction method}

In June 2003, three foreign investors acquired 26\% of AirAsia for the price of 98.8 million MYR. Thus, valuation of AirAsia based on this transaction is 380 million MYR. An earlier value is about 40 million MYR based on the debt amount assumed by the new owners to obtain 99.25\% of AirAsia in December 2001. 


\section{Price/earning multiple method}

Typical P/E used for valuation are "prevailing P/E multiple of matched firm" (Fleming, 132). However, one problem with this method is the availability of comparable publicly traded companies similar to the company being valued (Ryan 1989, 72). To value AirAsia, we can adopt a P/E used for a valuation of another low cost airline, Virgin Blue, which currently valued using Ryanair and easyJet P/E multiple of up to 17 times for 2004 (Hares, 2003). Based on the earnings of AirAsia for the period from July 2002 to June 2003 of 20 million MYR, the valuation of AirAsia is about 340 million MYR.

\section{Growth in Value}

Based on the above, we can estimate that the value of AirAsia has grown from about 40 million MYR in late 2001 to between 340-380 million MYR to mid 2003. In over one and a half years, AirAsia has grown in value by almost 8.5-9.5 times. On the other hand, based on shares outstanding and closing prices, Malaysia Airlines value has doubled from 2,479.4 million in January 2002 to 4,912.7 million MYR in July 2003. Obviously, Air Asia has grown more than Malaysia Airlines.

\section{CONCLUSION}

In the final analysis, we can conclude that AirAsia has successfully implemented its new strategy within its own rights, without affecting the incumbent, Malaysia Airlines. However, the impact of AirAsia strategic actions on Malaysian Airlines in the long term remains to be seen. AirAsia, still in its expansion phase, has seen its revenue, profits, passengers and value increase spectacularly in the past 22 months of operations as a low cost airline.

One of the key success factors is the people behind the transformation. The Chief Executive Officer, Tony Fernandes, has created a positive environment in the airline. He was ably advised by the Connor McCarthy, the former Chief Operating Officer of Ryanair, another low cost airline. Cost management is an important element in the airline management. Tony Fernandez has often said that cost, not other airlines, is AirAsia's enemy.

It will be interesting to follow AirAsia's future as it plans to go regional in South East Asia. Even before leaving Malaysia, AirAsia is already greeted by the major airlines in the region by these airlines' plans to start their own low cost units. In addition to other smaller airlines, this will be an interesting development to follow. We shall see if AirAsia can keep everyone flying around the region as it did in Malaysia under the company's tagline of "Now Everyone Can Fly".

\section{APPENDIX}

Table 1: The "Southwest Strategy"

\begin{tabular}{|l|}
\hline \multicolumn{1}{|c|}{ The "Southwest Strategy" } \\
\hline Fleet is made up of one type of aircraft \\
Service is limited on flights i.e. no free drinks or food or entertainment \\
Service is based one single class i.e. no premium or business class \\
Routes are point to point \\
Turnaround time (from touchdown to takeoff) in airports is short \\
Airports used are secondary airports and not major ones \\
Bookings made directly to airline, usually online, and not through travel agents \\
\hline
\end{tabular}

Source: Boone (2002) 
Figure 1: Number Of Passengers, 2001-2003



Figure 2: Revenues, 2001-2003

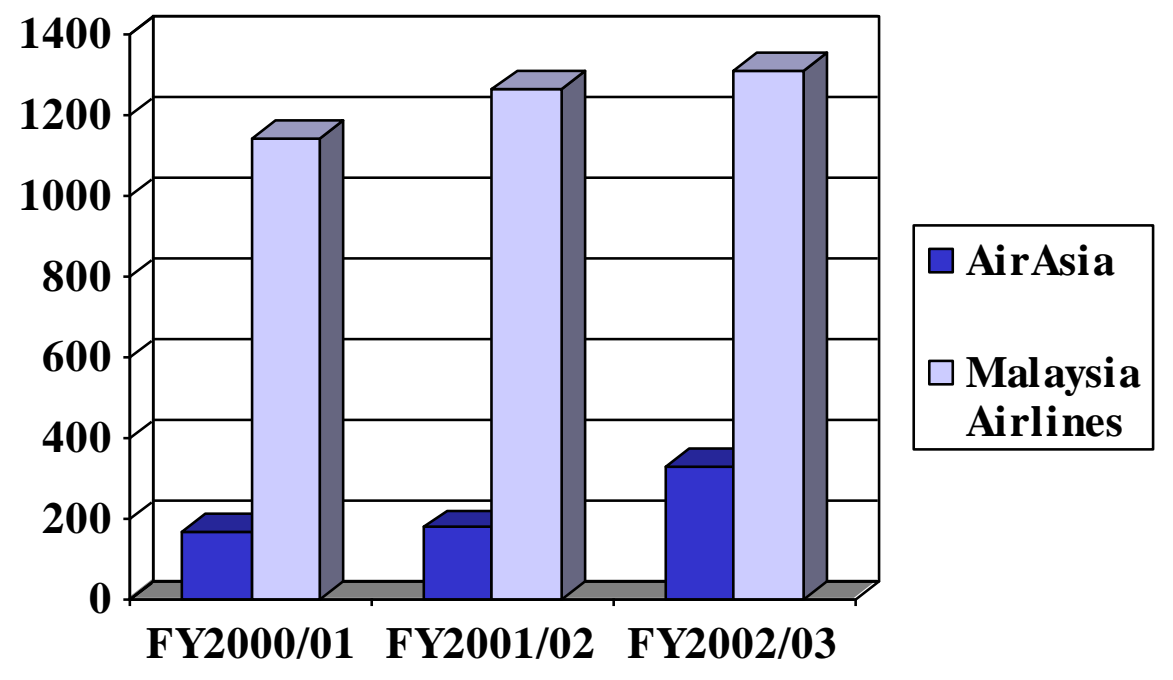


Figure 2: Movement Of Malaysia Airlines And Kuala Lumpur Stock Exchange Index

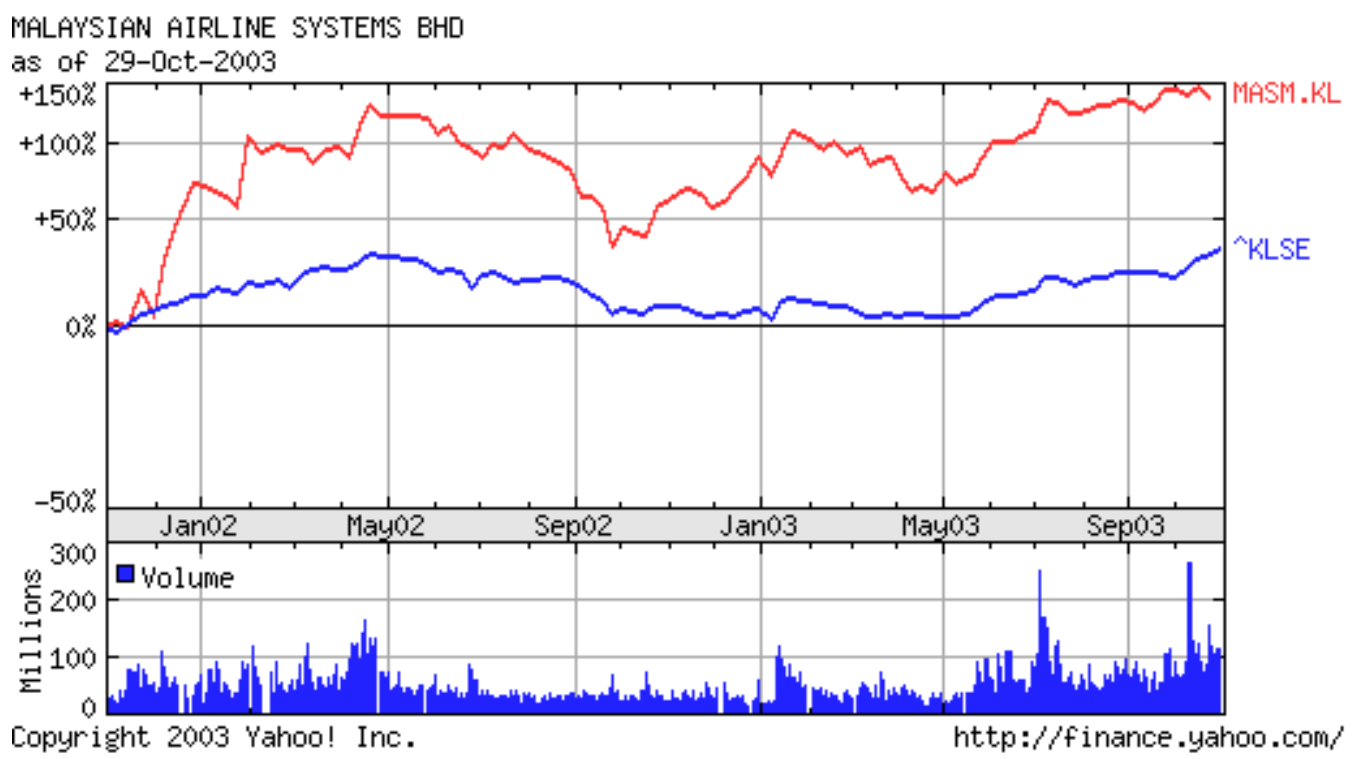

Table 2: Malaysia Airlines Closing Prices \& Volumes On Selected Dates

\begin{tabular}{|c|c|c|c|c|c|c|c|c|}
\hline Date & $\begin{array}{c}\text { Closing } \\
\text { Price }\end{array}$ & Volume & Date & $\begin{array}{c}\text { Closing } \\
\text { Price }\end{array}$ & Volume & Date & $\begin{array}{c}\text { Closing } \\
\text { Price }\end{array}$ & Volume \\
\hline 15-Jul-03 & 4.40 & 629,300 & 23-Jan-03 & 3.90 & 438,000 & 24-Jan-02 & 2.95 & 286,000 \\
\hline 14-Jul-03 & 4.40 & 820,600 & 22-Jan-03 & 3.92 & 352,000 & 23-Jan-02 & 2.95 & 466,000 \\
\hline 11-Jul-03 & 4.40 & 287,300 & 21-Jan-03 & 3.80 & 274,000 & 22-Jan-02 & 2.98 & 103,000 \\
\hline 10-Jul-03 & 4.36 & 139,000 & 20-Jan-03 & 3.64 & 127,000 & 21-Jan-02 & 2.99 & 164,000 \\
\hline 9-Jul-03 & 4.38 & 232,000 & 17-Jan-03 & 3.68 & 382,000 & 18-Jan-02 & 3.04 & 188,000 \\
\hline 8-Jul-03 & 4.42 & $1,373,700$ & 16-Jan-03 & 3.68 & 375,000 & 17-Jan-02 & 3.08 & 204,000 \\
\hline 7-Jul-03 & 4.42 & 2,145,400 & 15-Jan-03 & $\mathbf{3 . 6 2}$ & $\mathbf{4 8 2 , 0 0 0}$ & 16-Jan-02 & 3.00 & 424,000 \\
\hline 4-Jul-03 & $\mathbf{4 . 4 0}$ & $\mathbf{2 , 8 0 3 , 2 0 0}$ & 14-Jan-03 & 3.54 & 425,000 & 15-Jan-02 & $\mathbf{3 . 0 6}$ & $\mathbf{4 0 3 , 0 0 0}$ \\
\hline 3-Jul-03 & 4.28 & $2,792,400$ & 13-Jan-03 & 3.52 & $1,305,000$ & 14-Jan-02 & 3.04 & 216,000 \\
\hline 2-Jul-03 & 4.00 & 443,500 & 10-Jan-03 & 3.40 & 878,000 & 11-Jan-02 & 3.02 & 615,000 \\
\hline 1-Jul-03 & 3.92 & 732,600 & 9-Jan-03 & 3.36 & 67,000 & 10-Jan-02 & 3.12 & 239,000 \\
\hline 30-Jun-03 & 3.94 & 1,754,200 & 8-Jan-03 & 3.32 & 78,000 & 9-Jan-02 & 3.16 & $1,063,000$ \\
\hline 27-Jun-03 & 3.94 & $2,026,300$ & 7-Jan-03 & 3.28 & 297,000 & 8-Jan-02 & 3.08 & $1,183,000$ \\
\hline 26-Jun-03 & 3.90 & 445,100 & & & & 7-Jan-02 & 3.16 & 633,000 \\
\hline
\end{tabular}

Note: Announcement Date in Bold 


\section{REFERENCES}

1. Bonne, J. (2002). The airline business doesn't work ... but low-cost, short-haul airlines are changing the equation. MSNBC, 5 December 2002. http://www.msnbc.com/news/843222.asp?cp1=1 [Accessed 10 September 2003]

2. Fleming, G. (2003). Class notes for venture capital and private equity course (FINM7040) Canberra: The Australian National University

3. Hares, S. (2003). Patrick win shrinks Virgin Blue Australia float. Reuters News, 25 July 2003 http://factiva.com/ [Accessed 15 October 2003]

4. Jaafar, F. (2001) DRB-Hicom sold AirAsia (Original article in Malay language titled "DRB-Hicom jual AirAsia"). Utusan Malaysia, 6 September 2001. http://www.utusan.com.my/utusan/archive.asp?y=2001\&dt=0907\&pub=utusan_malaysia\&sec=korporat\&pg =ko_01.htm\&arc=hive [Accessed 15 September 2003]

5. Khanna, V. (2003). The no-frills CEO. The Business Times online edition, 5 July 2003 http://businesstimestest.asia1.com.sg/ story/0,4567,86676,00.html [Accessed 15 October 2003]

6. Malaysia Airlines (2002). Annual Report 2001/2002. Malaysia Airlines : Kuala Lumpur

7. Malaysia Airlines (2003). Annual Report 2002/2003. Malaysia Airlines : Kuala Lumpur

8. $\quad$ Porter, M.E. (1980). Competitive Strategy. New York: The Free Press

9. Prystay, C. (2002) The Sky's the Limit. The Far Eastern Economics Review, 5 December 2002

10. Ryan, C.R. (1989) Cashing in your chips: how to profitably sell your business. Homewood, Illinois : Dow Jones-Irwin

11. Sakran, S. (2002). A flying start. Malaysian Business, 16 July 2002, pp.23-34. http://proquest.umi.com/ [Accessed 12 September 2003]

12. Thomas, G. (2003) In tune with low fares in Malaysia. Air Transport World online http://www.atwonline. com/archives/contents/archive_contents_may03.cfm [Accessed 15 October 2003]

13. Travel Trade Report (2003). Air Asia plans no-frills services to BKK. Travel Trade Report online, 8 January 2003 http://www.ttreport.com/Newsfiles_2003/January03_news/airasia_bkk_jan8.htm [Accessed 15 October 2003]

14. Utusan Malaysia (2001), Less frills and more cheaper domestic air fares, says Tune Air. Utusan Malaysia, 12 December 2001. http://www.utusan.com.my/utusan/archive.asp?y=2001\&dt=1213\& pub=utusan_express\&sec=corporate\&pg=co_02.htm\&arc=hive [Accessed 15 September 2003]

15. Yahoo.com (2003). Shares and Index data for Malaysian Airlines and Kuala Lumpur Stock Exchange. $\mathrm{http} / / /$ finance.yahoo.com/q/bc?t=2y\&s=\%5EKLSE\&l=on\&z=m\&q=1\&c=MASM.KL [Accessed 25 and 30 October 2003] 